\title{
GROWTH PROMOTION AND PRESERVATION OF BARE ROOTED PLANTS OF DRACAENA SANDERIANA FOR COMMERCIALIZATION
}

\author{
C Gunathilake and KP Abeywickrama* \\ Department of Botany, University of Kelaniya, Kelaniya, Sri Lanka
}

Accepted: 7 February, 2011

\begin{abstract}
Bare rooted Dracaena sanderiana is a popular indoor plant with high commercial potential. $D$. sanderiana top cuttings were dipped in different growth promoting substances and preservatives to obtain disease free bare rooted plants within a short period of time. The six treatments tested included, three concentrations of chitosan, an organic root promoting extract, $\mathrm{NaOCl}$ and vinegar. Chitosan $0.002 \% \mathrm{w} / \mathrm{v}$ solution was found to be the most effective rooting substance. Plants grown in this solution had the highest root length $(8.7 \pm 0.8 \mathrm{~cm})$ and highest root number per plant $(44.7 \pm 2.2)$. Lowest number of Colony Forming Units (CFUs) of bacteria was recorded from the chitosan $0.002 \%$ w/v solution (18. $8 \pm 3.3)$ compared to tap water (control) $(233.2 \pm 7.7)$. Considering both preservative and growth promoting effects, chitosan $0.002 \%$ w/v solution can be recommended for the production of disease free bare rooted plants within a short period of time.
\end{abstract}

Key words: Chitosan, Dracaena sanderiana, Bare rooted plants, Export simulation

\section{INTRODUCTION}

Dracaena sanderiana (Lucky Bambo) is native to Cameroon in tropical West Africa. Varieties of $D$. sanderiana are popular in Sri Lanka as indoor plants at residences, hotels and restaurants. Plant cuttings of $D$. sanderiana can be grown into bare rooted plants in water or other root promoting media without soil around their root system. Bare rooted plants are economical form of plants but they require more care after planting to prevent microbial attack and desiccation. To overcome these problems preservatives such as Vinegar, $\mathrm{NaOCl}$ and Chitosan can be applied into rooting medium.

Chitosan is a technologically important and ubiquitous polysaccharide biopolymer. It is produced by partial alkaline N-deacetylation of chitin commercially extracted from shrimp and crab shells. It is known to possess biocide activity and growth promoting activity. Furthermore the biocide and growth promoting activity of chitosan could be enhanced through low-dose irradiation (Hein 2004). The organic rooting hormones, such as Napthylacetic acid (NAA), act as a plant growth regulator and produce significant effects in promoting development of pointed ends of the root system, resulting in relatively straighter and thicker roots.

\footnotetext{
*Corresponding author : kris@kln.ac.lk
}

In this study, three chitosan concentrations were tested along with an organic rooting compound to identify and compare their growth promoting activities. In addition, vinegar and $\mathrm{NaOCl}$ were also tested to compare their preservative effect on rooting and growth. The objective of these investigations were to explore the potential of commercial production of bare rooted $D$. sanderiana plant cuttings within a short period of time.

\section{MATERIALS AND METHODS}

\section{Plant material}

All experiments were carried out using top cuttings of $D$. sanderiana yellow variety. Top cuttings were freshly harvested from Serendib Horticulture Pvt. Ltd at Kalagedihene. Disease-free top-cuttings of same maturity and same size $(25 \mathrm{~cm})$ were selected. Cut ends were immersed in tap water and brought to the laboratory. Cuttings were cleaned to remove dust and dirt using wet cotton wool. Fresh weight of each cutting was recorded.

\section{Treatments}

The following six treatments were tested for their rooting, growth promoting and preservation ability. An organic rooting compound $(1 \% \mathrm{v} / \mathrm{v})$ (Root Most, LEILI Agrochemistry Co. Ltd, Beijing, China) was used to facilitate faster root growth whereas sodium hypochlorite $(\mathrm{NaOCl})$ solution 
$(0.05 \% \mathrm{v} / \mathrm{v})$ (Clorox, Malaysia) and vinegar solution $(0.05 \%$ v/v) (De Fonseka \& Sons Ltd, Sri Lanka) were used as preservatives. Three concentrations of Chitosan $(0.002 \% \mathrm{w} / \mathrm{v}, 0.003 \%$ $\mathrm{w} / \mathrm{v}$ and $0.004 \% \mathrm{w} / \mathrm{v}$ ) were used as root growth promoters. Chitosan solutions were prepared by dissolving chitosan flakes (Nuclear Research Institute, Vietnam) in $1 \% \mathrm{v} / \mathrm{v}$ Acetic Acid (Thretford Norfolk, UK) and $\mathrm{pH}$ of solution was adjusted to 5.7 with $1 \mathrm{M} \mathrm{NaOH}$ (BDH chemicals). Tap water was used as the untreated control.

The above solutions (@ 150ml) were filled separately into $250 \mathrm{ml}$ sterilized conical flasks. Two cuttings were dipped in each flask and the mouth covered with a piece of sponge. The treatments were replicated 6 times. Flasks were arranged according to a completely randomized design (CRD) on a bench in the Botanical garden, Department of Botany, University of Kelaniya. The cuttings were observed daily until the root system was established. Then bare rooted plants were separated from each flask.

\section{Assessment of root growth}

After root system was established, bare-rooted plants were isolated and their fresh weight, number of roots and length of roots were recorded.

\section{Assessment of preservative effect}

A dilution series was made up to $10^{-6}$ from the solution used for rooting. The dilution series were plated on nutrient agar medium (using $1 \mathrm{ml} /$ dilution). The nutrient agar plates were incubated for two- days at room temperature $\left(28 \pm 2^{0} \mathrm{C}\right)$. The Colony Forming Units of bacteria on nutrient agar were recorded. Using isolated colonies of bacteria, pure cultures were prepared and the bacteria were

Table 1: The number of roots per bare-rooted foliage of Dracaena sanderiana grown in the test solutions $(n=6)$.

\begin{tabular}{lc}
\hline \multicolumn{1}{c}{ Treatment } & $\begin{array}{c}\text { Number of Roots per } \\
\text { Cut Foliage }\end{array}$ \\
\hline Vinegar & $13.8 \pm 2.9^{\mathrm{a}}$ \\
Sodium hypochlorite $(\mathrm{NaOCl})$ & $17.2 \pm 2.0^{\mathrm{a}}$ \\
Organic rooting compound & $38.3 \pm 7.3^{\mathrm{b}}$ \\
Chitosan $0.002 \% \mathrm{w} / \mathrm{v}$ & $44.7 \pm 2.2^{\mathrm{b}}$ \\
Chitosan $0.003 \% \mathrm{w} / \mathrm{v}$ & $07.5 \pm 0.6^{\mathrm{a}}$ \\
Chitosan $0.004 \% \mathrm{w} / \mathrm{v}$ & $08.0 \pm 0.6^{\mathrm{a}}$ \\
Tap water (Control) & $11.0 \pm 2.1^{\mathrm{a}}$ \\
\hline
\end{tabular}

* Means having common letter (s) are not significantly different by one-way ANOVA parametric test. $(\mathrm{P}=0.000)$ identified up to genus level using Gram's staining and biochemical tests (Benson 2002).

\section{Isolation and identification of bacteria}

Gram's staining and biochemical tests such as endospore stain, motility determination, catalase activity, acid and gas production from glucose, citrate utilization, starch hydrolysis, indole production and oxidation or fermentation of glucose were performed. Morphological and biochemical characters of bacteria were observed and the isolated bacteria were identified using keys (Benson 2002, Cowan 1981)

\section{Statistical analysis}

Data obtained were analyzed by Minitab (version 14) and one-way ANOVA parametric test.

\section{RESULTS}

\section{Number of roots per bare-rooted plant}

The number of roots produced by each cut foliage of $D$. sanderiana was considered as a growth promoting parameter. D. sanderiana cuttings, incubated in chitosan $0.002 \% \mathrm{w} / \mathrm{v}$ and organic rooting compound gave significantly higher number of roots/ foliage (Table 1). However, there was no significant difference in root number produced by chitosan $0.002 \% \quad \mathrm{w} / \mathrm{v}$ and organic rooting compound.

\section{Root length}

Six roots having the highest root length were measured for each treatment. The root length of bare- rooted plants grown in $\mathrm{NaOCl}$ and $0.002 \% \mathrm{w} /$ $\mathrm{v}$ chitosan found to be significantly higher than those grown in other solutions (Table 2). Furthermore, there was a significant difference

Table 2: Root length of the bare-rooted foliage of Dracaena sanderiana grown in the test solutions $(n=6)$.

\begin{tabular}{lc}
\hline \multicolumn{1}{c}{ Treatment } & Root Length (cm) \\
\hline Vinegar & $5.6 \pm 0.8^{\mathrm{a}}$ \\
Sodium hypochlorite $(\mathrm{NaOCl})$ & $7.4 \pm 0.9^{\mathrm{a}}$ \\
Organic rooting compound & $2.6 \pm 0.3^{\mathrm{b}}$ \\
Chitosan $0.002 \% \mathrm{w} / \mathrm{v}$ & $8.7 \pm 0.8^{\mathrm{a}}$ \\
Chitosan $0.003 \% \mathrm{w} / \mathrm{v}$ & $5.4 \pm 0.4^{\mathrm{a}}$ \\
Chitosan $0.004 \% \mathrm{w} / \mathrm{v}$ & $6.1 \pm 0.8^{\mathrm{a}}$ \\
Tap water (Control) & $4.0 \pm 1.2^{\mathrm{a}, \mathrm{b}}$ \\
\hline
\end{tabular}

* Means having common letter (s) are not significantly different by one-way ANOVA parametric test. $(\mathrm{P}=0.000)$ 
Table 3: Percentage weight loss of cut Dracaena sanderiana foliage grown in the indicated solutions $(\mathrm{n}=$ 6)

\begin{tabular}{lc}
\hline \multicolumn{1}{c}{ Treatment } & $\begin{array}{c}\text { Percentage Weight } \\
\text { Loss }(\mathrm{g} / \mathbf{g}) *\end{array}$ \\
\hline Vinegar & $07.8 \pm 0.2$ \\
Sodium hypochlorite $(\mathrm{NaOCl})$ & $06.4 \pm 0.2$ \\
Organic rooting compound & $10.1 \pm 0.7$ \\
Chitosan $0.002 \% \mathrm{w} / \mathrm{v}$ & $11.6 \pm 0.2$ \\
Chitosan $0.003 \% \mathrm{w} / \mathrm{v}$ & $07.2 \pm 0.5$ \\
Chitosan $0.004 \% \mathrm{w} / \mathrm{v}$ & $01.8 \pm 0.6$ \\
Tap water & $11.4 \pm 0.2$ \\
\hline
\end{tabular}

* Means not significantly different $(\mathrm{p}=0.451)$

between root length in bare-rooted foliage grown in chitosan $0.002 \% \mathrm{w} / \mathrm{v}$ and tap water. The lowest root length was recorded for cuttings treated with $1 \%$ organic rooting compound.

\section{Percentage weight loss in bare-rooted foliage}

There was no significant difference in percentage weight loss in bare-rooted foliage treated with organic rooting compound, vinegar solution, chitosan and sodium hypochlorite solution $(\mathrm{NaOCl})$ (Table 3). However, foliage treated with $0.004 \% \mathrm{w} /$ $\mathrm{v}$ chitosan recorded the lowest weight loss.

\section{Bacteria associated with $D$. sanderiana bare- rooted foliage}

Colony Forming Units (CFU's) in $10^{-5}$ dilution of tap water was significantly higher than the CFU in $10^{-5}$ dilution of other treatments (Table 4). Further, the lowest CFU's of bacteria was observed in chitosan $0.002 \% \quad \mathrm{w} / \mathrm{v}$ solution whereas other chitosan solutions indicated higher CFU's.

\section{Isolation and identification of bacteria associated with $D$. sanderiana bare-rooted foliage}

Five different bacterial species were isolated from the solution used to root cuttings. Based on the Gram's stain and biochemical tests conducted, strain 3 was identified as Enterobacter sp. and strain 4 was identified as Escherichia sp. Other three strains could not identified up to the genus level.

\section{DISCUSSION}

In this study, an effort was taken to develop suitable foliage preservatives and growth promoting substances to obtain disease free bare rooted plants within a short period of time. According to the results, there was a significant difference in the number of roots produced by $D$. sanderiana top cuttings treated with chitosan $0.002 \%(\mathrm{w} / \mathrm{v})$ and root promoting extract solution.
Table 4: Colony forming units (CFUs) in $10^{-5}$ dilution of six treatment solutions and tap water

\begin{tabular}{lc}
\hline \multicolumn{1}{c}{ Treatment } & $\begin{array}{c}\text { Colony Forming Units } \\
\text { in 10 }\end{array}$ \\
\hline Vinegar & $57.2 \pm 4.5^{\mathrm{a}}$ \\
Sodium hypochlorite $(\mathrm{NaOCl})$ & $33.7 \pm 2.9^{\mathrm{a}}$ \\
Organic rooting compound & $48.3 \pm 2.7^{\mathrm{a}}$ \\
Chitosan $0.002 \% \mathrm{w} / \mathrm{v}$ & $18.8 \pm 3.3^{\mathrm{a}}$ \\
Chitosan $0.003 \% \mathrm{w} / \mathrm{v}$ & $110.5 \pm 3.2^{\mathrm{a}, \mathrm{b}}$ \\
Chitosan $0.004 \% \mathrm{w} / \mathrm{v}$ & $34.2 \pm 2.6^{\mathrm{a}}$ \\
Tap water & $233.2 \pm 7.7^{\mathrm{b}}$ \\
\hline
\end{tabular}

* Means followed by common letter (s) are not significantly different by one-way ANOVA parametric test. $(\mathrm{P}=0.000)$

The reason behind this observation could be due to the hormone present in organic root promoting extract. Sea weed extracts contain all major and minor plant nutrients, many trace elements, alginic acid, auxins, gibberellins and antibiotics. Alginic acid acts as a soil conditioner and auxins trigger better root growth promoting responses (http:// www.journeytoforever.org/farm library/ seaweed.html, 2009/11/13).

Chitosan $0.002 \% \mathrm{w} / \mathrm{v}$ solution was found to be as effective as the organic root promoting extract solution when used as a growth promoting substance. The time taken for the first few roots to emerge from cuttings was around two weeks. Cuttings were assessed after a period of 4 weeks when a stable root system was established in bare rooted plants. Highest mean root length was obtained in the case of $0.002 \%(\mathrm{w} / \mathrm{v})$ chitosan treated plants which was followed by $\mathrm{NaOCl}$ treated plants. Those values were significantly different and higher than the values obtained for other treatments including control. Previous research reported that root length of Chrysanthemum plant has increased up to $40 \%$ compared to control after application of oligochitosan of $10 \mathrm{ppm}$ to $150 \mathrm{ppm}$ (Hein 2004). In another instance, increased root lengths of $L$. latifolium, Eustoma grandiflorum and Crysanthemum morifolium after application of 100, 30 and $40 \mathrm{ppm}$ chitosan was reported (Luan et al. 2002).

Another objective of our research was to identify the preservative effect of six different treatments on bare rooted plants. The treatments act as biocide components in vase solutions thereby reducing the growth of microorganisms associated with cut foliages. When cut flower stems or foliage are placed in water, sap of cutting is bled into water and microorganisms grow rapidly feeding on them (Reid 2000). 
A study reported the production of 30 million bacteria on the vase solution within a day when freshly cut rose stems were dipped in a clean vase containing tap water (Reid 2000). These bacteria quickly clog up in the xylem tissue and interfere with the water conduction of the flower stem or cut foliage resulting in quick wilting of the flowers and leaves (Reid 2000). According to our results, the lowest colony forming units was observed in $0.002 \%(\mathrm{w} / \mathrm{v})$ treatment concentration of chitosan (18.8). A previous research indicated the inhibitory effect of both non-irradiated and irradiated chitosan on the growth of all fungal strains of Exobasidum vexans (foliar pathogen) (Hein 2004). It was also reported that the application of citric acid incorporated with chitosan- based coating to control pericarp browning of fresh longan fruit resulted in delayed pericarp browning (Apai et al. 2004). A similar research indicated coating of strawberries, blueberries and grapes with chitosan and essential oils resulted in lower fungal counts (Zivanovic et al. 2003).

Percentages weight loss of bare rooted plants treated with six treatment solutions were evaluated. Theoretically, fresh weight of bare-rooted plants should be higher than fresh weight of cut foliage since newly produced root mass also contributes to the fresh weight. However, according the results of our study, fresh weight had decreased. Treated cut foliage was placed on the bench of the botanical garden after placing in flasks. Transpiration of water may have contributed to weight loss. There was no significant difference of fresh weight loss of bare rooted plants among the seven treatments. However, higher percentage weight loss was reported from chitosan $0.002 \% \mathrm{w} / \mathrm{v}$, chitosan $0.004 \% \mathrm{w} / \mathrm{v}$ and tap water. In contrast, during a previous research it was indicated that, the fresh biomass of Chrysanthemum plants increased up to $68 \%$ after treating with of $100 \mathrm{ppm}$ of oligochitosan (Hein 2004). In another instance it was reported that fresh biomass of flower plants L. latifolium, Eustoma grandiflorum and Crysanthemum morifolium in tissue culture increased after treating them with irradiated chitosan (Farokhzad et al. 2008).

\section{CONCLUSION}

Chitosan $0.002 \%(\mathrm{w} / \mathrm{v})$ solution could be used to obtain disease free bare-rooted Dracaena sanderiana plants within a short period of time.

\section{ACKNOWLEDGEMENTS}

Gratefully acknowledge the technical assistance given by the staff members of Department of
Botany, and $\mathrm{Mr} \mathrm{P}$ Perera, Botanical Garden, University of Kelaniya. We thank Mr F Jiffrey, Serendib Horticulture, for the foliage cuttings and other assistance provided.

\section{REFERENCES}

Apai W, Sardsud V, Boonprasom P and Sardsud U (2004) Effects of citric acid incorporated with chitosan based coatings to control pericarp browning in fresh longan fruit, ISHS Acta Horticulture 787: International workshop on tropical and subtropical fruits.

Benson HJ 2002 Microbial Applications Laboratory Manual in General Microbiology. McGraw Hill, Boston.

Cowan ST 1981 Manual for the identification of medical bacteria. Cambridge University press, Cambridge.

Farokhzad AR, Khalighi A, Mostofi Y and Naderi R (2008) Effect of Some Chemical Treatment on Quality and Vase Life of Lisianthus (Eustoma grandiflora) Cut Flowers. Department of Horticultural Sciences, Faculty of Horticulture \& Plant Protection, Tehran University, College of Agriculture \& Natural Resources, Karaj, Iran.

Hein NQ 2004 Radiation Degradation of Chitosan and Some Biological Effects, Vietnam Atomic Energy Authority, Ho Chi Minh City, Viet Nam.

Luan L, Ha VTT, Hein NQ, Nagas FY and Kume T 2002 Effect of radiation degraded chitosan on growth promotion of flower plant in Tissue Culture. Journal of "Nippon Genshiryoku Kenkyujo" 144-154.

Reid MS 2000 Fresh Flower Foods. California Ornamental Research Federation News. 4 (3): 1 $-4$.

Zivanovic S, Mount JR, Draughon FA and Sams CE 2003 Edible chitosan coating as novel effective biopesticide. Department of Food Science and Technology, University of Tennessee and Department of Plant Science and Landscape System, University of Tennessee.

http://www.journeytoforever.org/farm library/ seaweed.html, November 2008

http://www.plant-care.com/lucky-bamboo.html, December 2008 